\title{
The Spatial Effect of Aging Population on Innovation in Entrepreneurship--Based on Empirical Analysis of Western China
}

\author{
Yunqing Su, Yi Li* \\ School of Economics and Management, Qinghai Nationalities University, Xining, Qinghai, China \\ *Corresponding Author.
}

\begin{abstract}
:
This study researches the impact of an aging population on Innovation in Entrepreneurship (IE), and applying fixed effects models (FE), mediated effects models and spatial lag regression model (SAR) to panel data of Western China (excluding Tibet) from 2004 to 2019.The results showed that an aging population and IE inverted significantly U-curve, and human capital plays a significant partial mediation between the two. A theoretical perspective based on the First Law of Geography, in the western China, aging population and IE are both positive spatial correlation, and both show the characteristics of "High-High" spatial agglomeration. Under the spatial model, aging population and IE also inverted U-curve.
\end{abstract}

Keywords: Aging population, Innovation in entrepreneurship, Human capital, Spatial effects.

\section{INTRODUCTION}

The trend of an aging population affects the long-term economic and social development, which is a major challenge facing the Chinese advance. According to Chinese seventh national survey data, on the end of 2020, 190.6 million people aged 65 and over, accounting for 13.5\% of the total population. According to the United Nations, China is close to deep aging (The elderly population aged 65 and above accounted for more than 14\%). The ever-increasing aging population restricts the continual mass of human capital, and human is the most critical reason for corporate innovation. Studying the impact of aging population on innovation in entrepreneurship (IE) is significant.

As the gradual decline of the demographic dividend, how to effectively display IE is a key issue for the western Chinese economic development [1]. In 2000, number of patent authorization in the western China was 11,298. By 2019, the number of patent authorizations reached 283,992, which is nearly 25 times that of 2000. The IE in the western China has 
increased exponentially. As the aging population in western China continues to deepen, how to achieve sustainable development of IE has become increasingly prominent.

Whether a turning point in the aging population is an academic focus. From a macro view, under the inertia of the family planning policy, the aging Chinese population will continue to deepen, which will lessen labor and hinder technological progress [2]. Based on the labor market view, aging will promote the labor market transforms to the demand for skilled labor, and promote innovation [3]. From a micro level, the aging of corporate employees will inhibit IE [4]. Individual age and technological innovation are a hump-shaped. Young people love technological innovation more than the elderly [5]. In recent years, scholars have verified the inverted U-shaped between aging population and IE, and calculated the inflection point of aging population [6]. No unanimous conclusions of the impact of an aging population on IE.

This study makes two contributions to the literature. First, based on the theory of the First Law of Geography, we make up for the shortfall in the aging population on IE literature by applying the spatial measurement model. Second, research focuses on the western region there is less attention, it helps to identify the theoretical and empirical differences in impacts of an aging population on IE. We aim to empirically examines that aging population impacts on IE at the spatial level, that can serve western regional policy makers.

\section{RESEARCH HYPOTHESIS}

2.1 Nonlinear Effects of Age on Innovation in Entrepreneurship at the Macro Level

Existing research results on the impact of aging population on innovation in entrepreneurship (IE) can be divided into the following three types:

First, the negative impact: the elderly will inhibit innovative ability as the decline of their physiological work and cognitive level, and an aging society will inhibit innovation [7]. Early Chinese scholars also believed the elderly would increase the social pension load [8]. From a micro-enterprise view, the aging of employees will inhibit enterprise innovation because of the low turnover rate of employees and the high enterprise financial load [4].

Second, positive impact: some studies have concluded that scientists' research results and quality reached their peak in middle age [9]. The workforce aging can positively effect innovation performance [10]. In innovation management, mature labor force has an advantage over young people because of rich experience [11]. The elderly with higher education level makes more advantages in the labor market [12], and has promoted technological progress [13] and long-term economic growth [14]. 
Third, the inverted $\mathrm{U}$-shaped impact: existing research has verified that an aging population and technological innovation Error! Reference source not found., enterprise innovation [16] inverted U-shaped. It is estimated that when an aging population exceeds $10.21 \%$, it will inhibit the innovation [17].Throughout the empirical research, we hypothesize that:

Hypothesis 1 (H1). Aging population and IE inverted U-shaped.

\subsection{The Intermediary Effect of Human Capital}

Human capital shows a positive correlation with innovation in entrepreneurship (IE), and the aging population is a major factor influencing human capital. Most scholars believe the aging population will increase the family's medical load [18] and pension load [13], which will crowd out investment in education and inhibit human capital. Meanwhile, other scholars believe the aging population benefits human capital [19] [20]. improving human capital and deepening aging population may be mutual influence. The store of human capital will enhance the enterprises innovation. It is necessary to sort out the mechanism of aging population affecting IE from the human capital view. Based on this, we hypothesize that:

Hypothesis 2 (H2). Human capital has an intermediary effect between an aging population and IE.

\subsection{Nonlinear Effects of Age on Innovation in Entrepreneurship at the Spatial Level}

According to the first law of geography [21], economic development is dependent on the spatial effects, especially neighboring provinces. Many scholars have discussed the spatial effects of innovation in entrepreneurship (IE) [22][24]. An aging population shows spatial agglomeration [25][26] and spatial differentiation characteristics [27][29]. Some scholars have analyzed the impact of an aging population on technological innovation from the spatial effects [30][32], but few scholars apply spatial panel model for the effect of an aging population on IE. As mentioned earlier, the spatial spillover of an aging population is likely to affect the IE of neighboring provinces. Based on this, we hypothesize that:

Hypothesis 3 (H3). A spatial effect on the inverted U-shaped between aging population and IE.

\section{MODEL}

\subsection{Data Source}


This study takes the panel data for 11 provinces in western China from 2004 to 2019.The 11 provinces include Chongqing, Shanxi, Sichuan, Qinghai, Yunnan, Guizhou, Gansu, Neimenggu, Guangxi, Ningxia, Xinjiang). The Original data were sourced from the China Statistical Yearbook, China Population and Employment Statistical Yearbook, and the EPS data platform.

\subsection{Variables}

This study uses the patent to measure innovation in entrepreneurship (IE) based on past studies [33][34], patents include three types: invention, utility model, and design. We believe the number of patent grants is more representative of innovation quality than the number of patent applications [35]. Besides, Robustness Check, the number of patent applications is used. Concern the aging population (AP), measured as the proportion of the population over 65 in the total population [36]. Controlled variables include Macro Control (MC) [37], Economic Development (lnED) [38], Information Level (IL) [39], Transport Conditions (TC) [40], Ecological Protection (EP) [41]. We use human capital as an intermediary variable, and the measure refer to existing studies [42]. TABLE I shows the definitions and descriptive statistics of each variable.

TABLE I. Descriptive statistics of the variables (Sample size: 165)

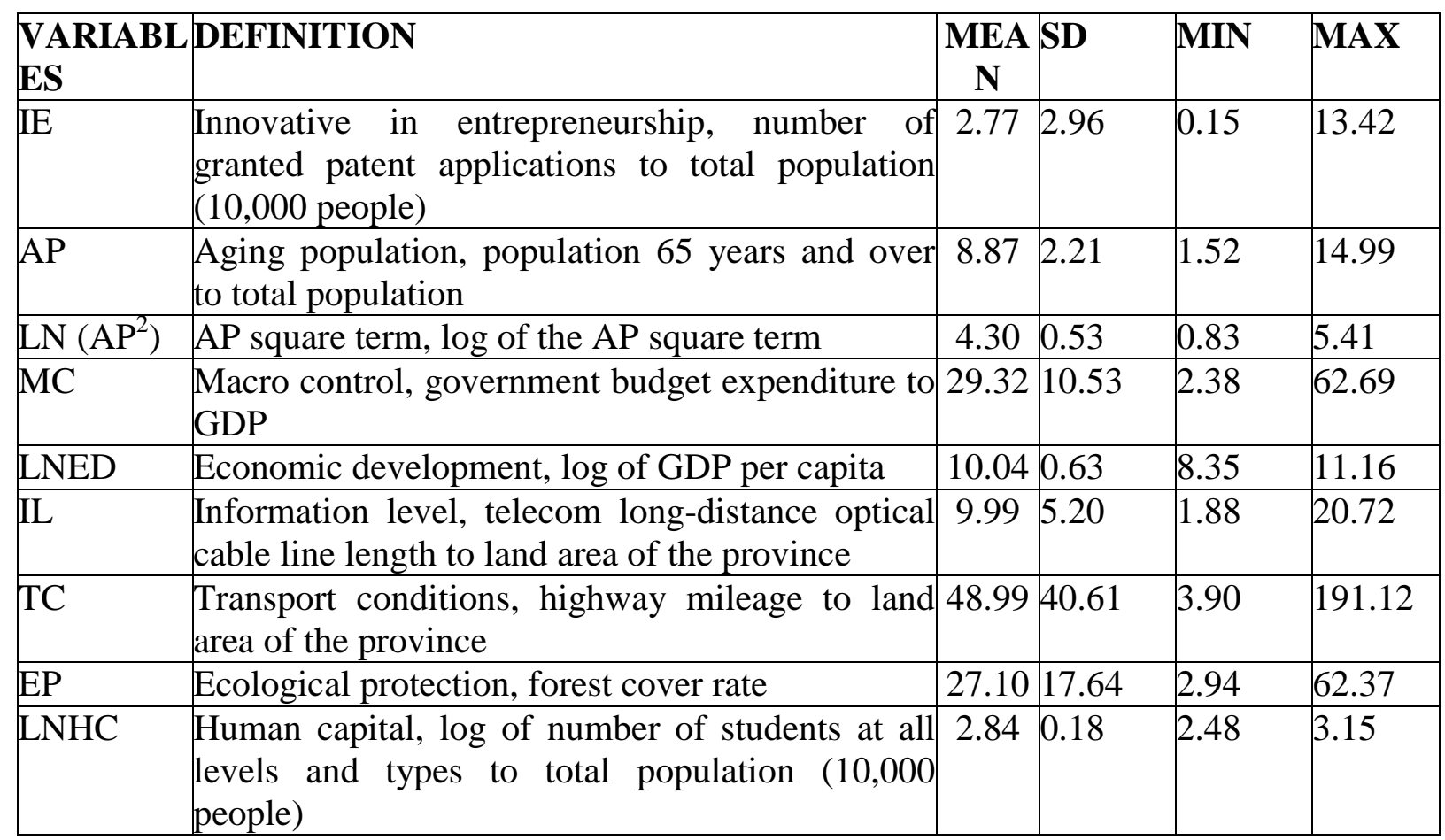




\subsection{Model}

\subsubsection{Fixed effects model}

The literature review found the aging population (AP) has a nonlinear effects with innovation in entrepreneurship (IE). Based on past studies, the fixed effects model is as follows:

$$
I E n_{i, t}=\beta_{0}+\beta_{1} \mathrm{AP}_{i, t-1}+\beta_{2} \operatorname{LnAP}_{i, t-1}^{2}+\sum_{k} \beta_{k} \text { Control }_{i, t-1}+\varepsilon_{i, t}
$$

In the equation, $I E_{i, t}$ represents the innovation in entrepreneurship for the th province in the ith year. $\mathrm{AP}_{i, t-1}$ and $\operatorname{LnAP^{2}}{ }_{i, t-1}$ refer to the aging population and the log of the quadratic forms of AP, respectively, for the $\mathrm{t}-1$ th province in the ith year. The control variables include $M C_{i, t-1}, \ln E D_{i, t-1}, I L_{i, t-1}, T C_{i, t-1}, E P_{i, t-1} . \varepsilon_{i, t}$ represents the random disturbance term. From equation (1), if $\beta_{1}>0, \beta_{2}<0$, the aging population and innovation in entrepreneurship inverted U-shaped [43]. All explanatory variables lag one period to avoid endogenous problems [44]. Some explanatory variables take the logarithm to remove heteroscedasticity.

\subsubsection{Mediating effect model}

Further, to test the intermediary effect of human capital between the aging population (AP) and innovation in entrepreneurship (IE), based on equation (1), the Mediating effect model following [45]:

$$
\begin{aligned}
& \operatorname{IEn}_{i, t}=\beta_{0}+\beta_{1} \mathrm{AP}_{i, t-1}+\beta_{2} \operatorname{LnAP}_{i, t-1}^{2}+\sum_{k} \beta_{k} \text { Control }_{i, t-1}+\varepsilon_{i, t} \\
& M_{i, t}=\gamma_{0}+\gamma_{1} \mathrm{AP}_{i, t-1}+\gamma_{2} \operatorname{LnAP}_{i, t-1}^{2}+\sum_{k} \gamma_{k} \text { Control }_{i, t-1}+\varepsilon_{i, t} \\
& I E_{i, t}=\varphi_{0}+\varphi_{1} \mathrm{AP}_{i, t-1}+\varphi_{2} \operatorname{LnAP}_{i, t-1}^{2}+\varphi_{3} M_{i, t}+\sum_{k} \varphi_{k} \text { Control }_{i, t-1}+\varepsilon_{i, t}
\end{aligned}
$$

In the equation above, $\beta_{1}$ and $\varphi_{1}$ represent the total effect and the direct effect respectively, and the intermediary effect is $\gamma_{1} \times \varphi_{2}$ or $\varphi_{1}-\beta_{1} . M_{i, t}$ represents the intermediary variable of human capital. When $\varphi_{1}-\beta_{1} \neq 0$, the intermediary effect of human capital was significant.

\subsubsection{Spatial measurement model}

Based on the spatial contiguity matrix, to examine the Moran spatial correlation of the aging population (AP) and innovation in entrepreneurship (IE). When Moran's $\mathrm{I}=0$, it is 
random in space. When Moran's I > 0 suggests positive spatial correlation, the larger the value, the tighter the spatial effect; when Moran's I < 0 suggests negative spatial correlation, the smaller the value, the bigger the spatial gap. The equation is as follows [46]:

$$
I=\frac{n \sum_{i} \sum_{j} w_{i j}\left(x_{i}-\bar{x}\right)\left(x_{j}-\bar{x}\right)}{\left(\sum_{i} \sum_{j} w_{i j}\right) \sum_{i}\left(x_{i}-\bar{x}\right)^{2}}
$$

Taking spatial lag regression model (SAR) to research the spatial effect of AP on IE. The equation is as follows [47]:

$$
I E_{i, t}=\alpha_{0}+\rho W_{i, t} I E_{i, t}+\alpha_{1} \mathrm{AP}_{i, t-1}+\alpha_{2} L n A P_{i, t-1}^{2}+\sum_{k} \alpha_{k} \operatorname{Control}_{i, t-1}+\varepsilon_{i, t}
$$

In the above formula, $W$ is the contiguity weight matrix, ${ }^{\rho}$ is the spatial correlation coefficient of IE, the rest variables are the same as formula (1).

\section{RESULTS}

\subsection{Unit Root Tests}

The sample data studied are long-panel data. Each variable adopts unit root test to ensure the reliability of the results, and using LLC test, IPS test, and Fisher-ADF test. TABLE II shows the unit root test results. All variables have passed two or three types of unit root tests, and the data are at a stable level at the $5 \%$ or $1 \%$ level.

\section{TABLE II. Unit root test results}

\begin{tabular}{|l|l|l|l|}
\hline VARIABLES & TEST TYPE & SIGNIFICANCE & RESULT \\
\hline IE, MC & IPS, FISHER-ADF & IPS $* *$, FISHER-ADF**S STATIONARITY \\
\hline AP, LN $\left(\mathrm{AP}^{2}\right)$, IL, TC, EPLLC, IPS, FISHER-ADF & ALL *** & STATIONARITY \\
\hline LNED, LNHC & LLC, FISHER-ADF & ALL $* * *$ & STATIONARITY \\
\hline
\end{tabular}

Note: $* * * * * *$ indicate the significance level of $1 \%, 5 \%$, and $10 \%$ respectively.

\subsection{Model Selection}

Both the F test and the Hausman test reject the null hypothesis at the $1 \%$ statistical level, and primary panel regression selected fixed effect model. Further, the panel data adopts the tests of heteroscedasticity between groups, cross-sectional correlation, and autocorrelation 
within groups to select a better panel data model.

The Wald statistic of the heteroscedasticity test is 235.34 , and the $\mathrm{P}$ value is 0.0000 . The F-test statistic of the within-group autocorrelation test is 14.62 , and the $\mathrm{P}$ value is 0.0034 . The LM test statistic of the cross-sectional correlation test is 116.94 , and the $\mathrm{P}$ value is 0.0000 . These test results show the long panel data model has heteroscedasticity between groups, cross-sectional correlation, and autocorrelation within groups. Using FGLS estimation method can provide effective and robust coefficients to correct the problems [48].

\subsection{Results of Fixed Effects Model}

Based on equation (1), TABLE III compare the linear and non-linear effects between an aging population (AP) and innovation in entrepreneurship (IE), and show two robustness estimation results.

TABLE III. Linear effects and nonlinear effects of AP on IE in western China

\begin{tabular}{|c|c|c|c|c|}
\hline \multirow[t]{3}{*}{ VARIABLES } & \multicolumn{4}{|c|}{\begin{tabular}{|l|l|} 
LINEAR EFFECTS & NON-LINEAR EFFECTS \\
\end{tabular}} \\
\hline & MODEL I & MODEL II & MODEL III & MODEL IV \\
\hline & $\overline{\mathrm{FE}}$ & FE & FGLS-PSAR1 & FE \\
\hline $\mathrm{AP}$ & $\begin{array}{l}0.585^{* * * * *} \\
(0.119)\end{array}$ & $\begin{array}{l}2.142^{* * * * *} \\
(0.241)\end{array}$ & $\begin{array}{l}0.800^{* * * * * *} \\
(0.032)\end{array}$ & 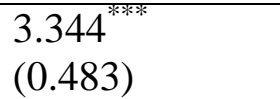 \\
\hline $\mathrm{LN}\left(\mathrm{AP}^{2}\right)$ & & $\begin{array}{l}-4.722^{\text {**** }} \\
(0.661)\end{array}$ & $\begin{array}{l}-1.734^{* * *} \\
(0.091)\end{array}$ & $\begin{array}{l}-7.216 \\
(1.327)\end{array}$ \\
\hline $\mathrm{MC}$ & $\begin{array}{l}-0.105^{* * *} \\
(0.024)\end{array}$ & $\begin{array}{l}-0.078^{* * * *} \\
(0.021)\end{array}$ & $\begin{array}{l}-0.046^{* * *} \\
(0.003)\end{array}$ & $-0.110^{* * * *}(0.042)$ \\
\hline LNED & $\begin{array}{l}3.729^{\text {***** }} \\
(0.474)\end{array}$ & $\begin{array}{l}2.874^{\text {**** }} \\
(0.427)\end{array}$ & 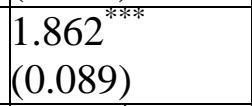 & $\begin{array}{l}6.088^{\text {**** }} \\
(0.857)\end{array}$ \\
\hline IL & $\begin{array}{l}-0.362^{\text {*** }} \\
(0.069)\end{array}$ & $\begin{array}{l}-0.330 \\
(0.060)\end{array}$ & $\begin{array}{l}-0.019^{*} \\
(0.009)\end{array}$ & $\begin{array}{l}-0.676 \\
(0.120)\end{array}$ \\
\hline TC & $\begin{array}{l}0.019^{* * *} \\
(0.009)\end{array}$ & $\begin{array}{l}0.013 \\
(0.008)\end{array}$ & 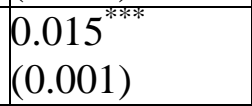 & $\begin{array}{l}0.020 \\
(0.016)\end{array}$ \\
\hline $\mathrm{EP}$ & $\begin{array}{l}-0.001 \\
(0.031)\end{array}$ & $\begin{array}{l}0.017 \\
(0.026)\end{array}$ & $\begin{array}{l}-0.026^{* * *} \\
(0.002)\end{array}$ & $\begin{array}{l}0.033 \\
(0.053)\end{array}$ \\
\hline CONSTANT & $\begin{array}{l}-34.132^{* * * *} \\
(3.2055)\end{array}$ & $\begin{array}{l}-20.289^{\text {**** }} \\
(3.382)\end{array}$ & $\begin{array}{l}-13.996 \\
(0.8830)\end{array}$ & 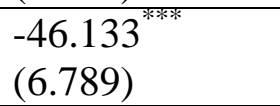 \\
\hline R-SQUARED & 0.786 & 0.841 & & 0.828 \\
\hline F TEST & $\begin{array}{l}10.39 \\
{[0.000]}\end{array}$ & $\begin{array}{l}16.48 \\
{[0.000]}\end{array}$ & & $\begin{array}{l}18.61 \\
{[0.000]}\end{array}$ \\
\hline WALD TEST & & & $\begin{array}{l}2446.44 \\
{[0.0000]}\end{array}$ & \\
\hline
\end{tabular}


Note: ***,**,* indicate the significance level of $1 \%, 5 \%$, and $10 \%$ respectively. The value in () indicates the standard error of the estimated coefficient, the value in [] represents the $p$ value.

The model I and model II show that a significant positive correlation between AP and IE. After adding the square term of $\mathrm{AP}, \mathrm{Ln}\left(\mathrm{AP}^{2}\right)$ and IE significant show negative effects. The R2 of Model II is 0.8415 , and the equation has a good fit. The estimated coefficients of AP and $\mathrm{ln}$ $\left(\mathrm{AP}^{2}\right)$ are 2.1415 and -4.7223 respectively at the $1 \%$ significance level, showing that an aging population and innovation in entrepreneurship inverted U-shaped. It is confirmed the new seniors in the company may have a comparative advantage. Based on their work experience, they have gathered a wealth of knowledge for innovation. The knowledge spillover created in the early stage of aging will hasten the innovation [36]. However, when the degree of aging gradually deepens, the increase of the financial load of the government, enterprises, families, weakening the innovation of enterprises [49]. The result supports Hypothesis 1.

The article replaces the regression method and the dependent variable as robustness check. According to the FGLS estimation results (TABLE III, model III), The direction of the coefficients is consistent with model II, and they are both significant at the $1 \%$ statistical level. The test again confirms that when AP exceeds a certain critical value, its crowding-in effect on IE becomes crowding-out effect.

Re-measure IE with the number of patent applications per 10,000 people, keeping the control variables constant, and TABLE III shows the results (model IV). The R2 of model IV is 0.8289 , which suggests the equation is well-fitted. The results of model IV and model II are the same. Hypothesis 1 is verified again and has certain robustness.

\subsection{Results of Mediating Effect Model}

Based on equation (2)-(4), TABLE IV shows that whether human capital exists mediating effect between an aging population (AP) and innovation in entrepreneurship (IE).

From column (1) in TABLE IV, suggesting the aging population in western China will inhibit human capital. From the comparison of column (2) and column (3), the estimated coefficient of the mediating effect is $-0.445\left(\varphi_{1}-\beta_{1}\right)$, through the Sobel test, shows the partial mediating effect of human capital is significant. Among the inverted U-shaped with AP on IE, human capital contributed $41.42 \%$ by the mediating effect. The coefficient of AP has risen from 1.074 to 1.518. The coefficient of $\mathrm{Ln}\left(\mathrm{AP}_{2}\right)$ has dropped from -2.6812 to -3.6559 . The coefficient of human capital is significantly positive. Therefore, human capital can 
Article History: Received: 10 May 2021 Revised: 20 June 2021 Accepted: 18 July 2021 Publication: 31 August 2021 enhance the inverted U-shaped effects between AP and IE. As the aging population to deepen, lessening the effective supply of labor in western China, and inhibiting innovation in entrepreneurship. We should pay attention to the store of human capital and promote innovation in entrepreneurship [50].

TABLE IV. Mediating effect of human capital between AP and IE

\begin{tabular}{|l|l|l|l|}
\hline VARIABLES & $(\mathbf{1})$ & $\mathbf{( 2 )}$ & $\mathbf{( 3 )}$ \\
\cline { 2 - 4 } & $\mathbf{L N H C}$ & LNIE & LNIE \\
\hline AP & $-0.129^{* * *}$ & $1.073^{* * *}$ & $1.518^{* * *}$ \\
& $(0.017)$ & $(0.206)$ & $(0.232)$ \\
\hline LN $\left(\mathrm{AP}^{2}\right)$ & $0.284^{* * * *}$ & $-2.681^{* * *}$ & $-3.655^{* * * *}$ \\
& $(0.062)$ & $(0.754)$ & $(0.773)$ \\
\hline LNHC & & & $3.429^{* * *}$ \\
& & & $(0.940)$ \\
\hline MC & 0.001 & $-0.028^{* *}$ & $-0.033^{* *}$ \\
& $(0.001)$ & $(0.014)$ & $(0.014)$ \\
\hline LNED & $-0.083^{* * *}$ & $2.560^{* * *}$ & $2.847^{* * *}$ \\
& $(0.019)$ & $(0.235)$ & $(0.239)$ \\
\hline IL & 0.003 & -0.003 & -0.013 \\
& $(0.002)$ & $(0.029)$ & $(0.028)$ \\
\hline TC & $0.001^{* * * *}$ & $0.017^{* * *}$ & $0.013^{* * *}$ \\
& $(0.001)$ & $(0.004)$ & $(0.004)$ \\
\hline EP & 0.001 & $-0.017^{* *}$ & $-0.021^{* *}$ \\
& $(0.001)$ & $(0.009)$ & $(0.009)$ \\
\hline CONSTANT & $3.426^{* * * * * *}$ & $-20.471^{* * *}$ & $-32.222^{* * * *}$ \\
& $(0.214)$ & $(2.621)$ & $(4.092)$ \\
\hline R-SQUARED & 0.588 & 0.774 & 0.792 \\
\hline SOBEL & & & -0.444 \\
[P-VALUE] & & $0.001]$ \\
\hline OBSERVATIONS & 165 & 165 & 165 \\
\hline
\end{tabular}

Note: $* * *, * *, *$ indicate the significance level of $1 \%, 5 \%$, and $10 \%$ respectively. The value in () indicates the standard error of the estimated coefficient, the value in [] represents the $p$ value. 


\subsection{Results of Spatial Measurement Model}

\subsubsection{Spatial correlation analysis}

Based on equation (5), TABLE V shows the Global Moran's I and P values of an aging population (AP) and innovation in entrepreneurship (IE) in western China. AP lags one period to avoid endogenous problems (in section 3.3), its spatial correlation test is from 2004 to 2018.

In TABLE V, the P value of Global Moran's I of IE in western China from 2005 to 2010 failed the significance test, but the Global Moran's I was between 0.1 and 0.3 at the $10 \%$ statistical level in 2010-2019. the P value of Global Moran's I of AP in western China in most years passed the significance test, and the Global Moran's I was between 0.1-0.2. In general, suggesting IE and AP in western China have a strong positive spatial correlation. About the spatial effect of AP on IE needs further check.

\section{Table V. The Global Moran's I of IE and AP in western China}

\begin{tabular}{|c|c|c|c|c|c|c|c|}
\hline \multicolumn{4}{|c|}{$\begin{array}{l}\text { THE SPATIAL CORRELATION } \\
\text { TEST OF IE }\end{array}$} & \multicolumn{4}{|c|}{$\begin{array}{l}\text { THE SPATIAL CORRELATION } \\
\text { TEST OF AP }\end{array}$} \\
\hline YEARS & $\begin{array}{l}\text { MORAN } \\
\text { I }\end{array}$ & $\begin{array}{ll}\text { Z } \\
\text { VALUE }\end{array}$ & $\begin{array}{l}\text { P } \\
\text { VALUE }\end{array}$ & YEARS & $\begin{array}{l}\text { MORAN } \\
\text { I }\end{array}$ & $\begin{array}{ll}\text { Z } \\
\text { VALUE }\end{array}$ & $\begin{array}{l}\text { P } \\
\text { VALUE }\end{array}$ \\
\hline 2005 & 0.018 & 0.887 & 0.188 & 2004 & 0.187 & 1.911 & 0.028 \\
\hline 2006 & 0.074 & 1.258 & 0.104 & 2005 & 0.133 & 1.532 & 0.063 \\
\hline 2007 & 0.099 & 1.282 & 0.100 & 2006 & 0.130 & 1.386 & 0.083 \\
\hline 2008 & 0.090 & 1.136 & 0.128 & 2007 & 0.123 & 1.340 & 0.090 \\
\hline 2009 & 0.093 & 1.162 & 0.123 & 2008 & 0.102 & 1.225 & 0.110 \\
\hline 2010 & 0.107 & 1.235 & 0.108 & 2009 & 0.128 & 1.381 & 0.084 \\
\hline 2011 & 0.157 & 1.618 & 0.053 & 2010 & 0.175 & 1.649 & 0.050 \\
\hline 2012 & 0.184 & 1.761 & 0.039 & 2011 & 0.199 & 1.787 & 0.037 \\
\hline 2013 & 0.181 & 1.735 & 0.041 & 2012 & 0.179 & 1.717 & 0.043 \\
\hline 2014 & 0.198 & 1.809 & 0.035 & 2013 & 0.178 & 1.704 & 0.044 \\
\hline 2015 & 0.185 & 1.787 & 0.037 & 2014 & 0.148 & 1.522 & 0.064 \\
\hline 2016 & 0.153 & 1.591 & 0.056 & 2015 & 0.100 & 1.204 & 0.114 \\
\hline 2017 & 0.184 & 1.737 & 0.041 & 2016 & 0.092 & 1.168 & 0.121 \\
\hline 2018 & 0.208 & 1.893 & 0.029 & 2017 & 0.075 & 1.050 & 0.147 \\
\hline 2019 & 0.232 & 1.986 & 0.024 & 2018 & 0.171 & 1.635 & 0.051 \\
\hline
\end{tabular}

Note: The data in the table are estimated using Stata 15.1 software.

Using ArcGis10.5 software to draw Moran scatter plots, Fig 1 and Fig 2 show the local Moran's I distribution of the aging population (AP) and innovation in entrepreneurship (IE) in western China. 

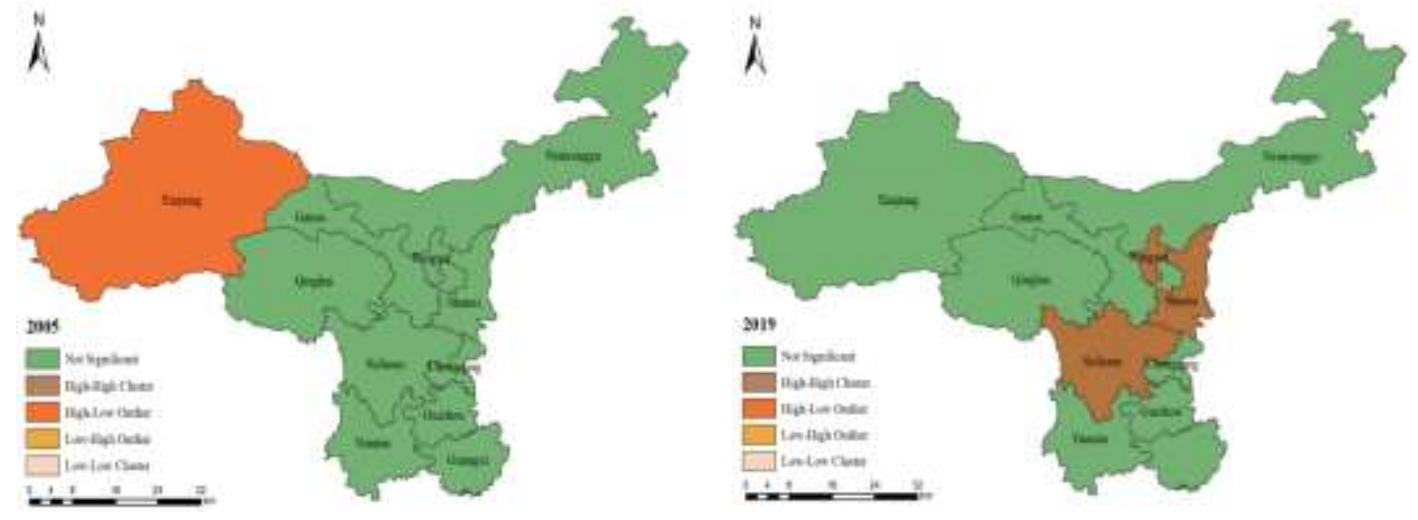

Fig 1: local spatial cluster map of IE in western China (excluding Tibet) in 2005 and 2019

In Fig 1, IE in western China show a spatial agglomeration, and the characteristics are becoming more prominent. In 2005, the "High-Low" clusters were distributed in Xinjiang, indicating Xinjiang's IE is high and neighboring provinces are low, which has a restraining effect on provinces with low level of IE. In 2019, the "High-High" clusters were distributed in Sichuan, Shaanxi and Ningxia, indicating IE of itself and neighboring provinces are high.
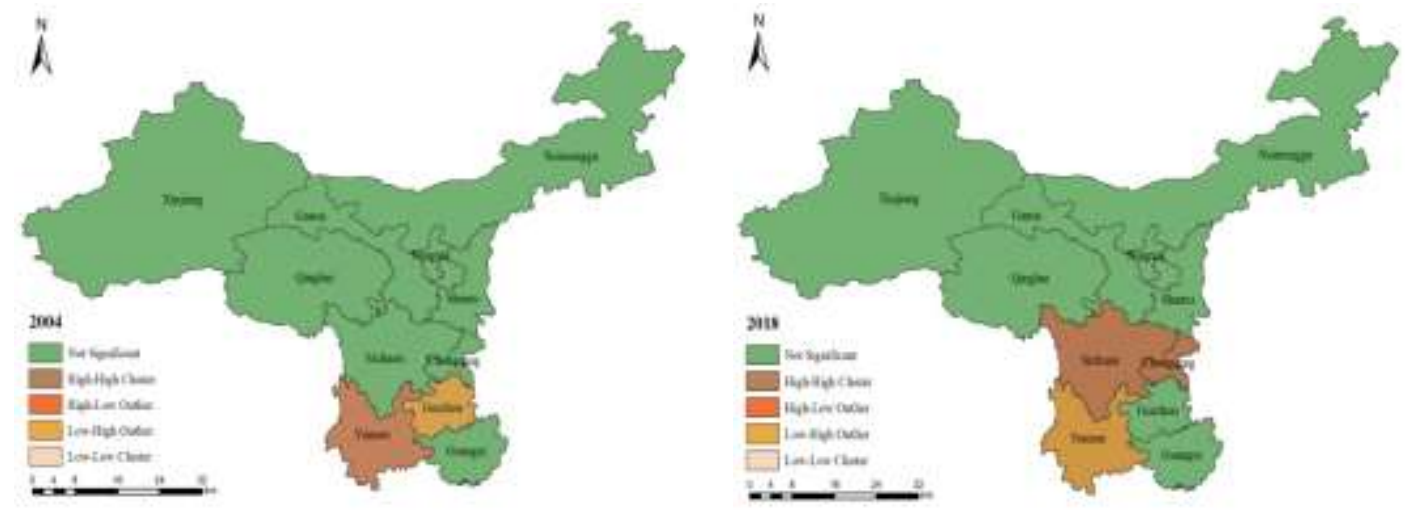

Fig 2: local spatial cluster map of AP in western China (excluding Tibet) in 2004 and 2018

In Fig 2, IE in western China show a spatial agglomeration "high in the southwest and low in the northwest". In 2004, the "High-High" clusters were distributed in Yunnan, indicating AP in own and neighboring provinces is high. The "Low-High" clusters are distributed in Guizhou, indicating its AP is low and neighboring provinces are high. The high-level provinces have a polarizing effect on low-level provinces. In 2019, the "High-High" clusters were distributed in Sichuan and Chongqing, and the "Low-High" clusters were distributed in Yunnan. 


\subsubsection{Spatial effect analysis}

Using equation (6), based on the spatial lag regression model (SAR), TABLE VI show the spatial effect of the aging population (AP) on innovation in entrepreneurship (IE) in western China.

From the column (1) In TABLE VI, the coefficients of AP and $\mathrm{Ln}\left(\mathrm{AP}^{2}\right)$ are 1.474 and -3.270 at the $1 \%$ statistical level, respectively. The spatial autocorrelation coefficient $\rho$ is 0.416 at the $1 \%$ statistical level, indicating a spatial effect on the inverted U-shaped between AP and IE. The result supports Hypothesis 3.

From the decomposition of spatial effects, the coefficient of direct promotion effect of AP on IE (the effect on local IE) is 1.5745 , and the coefficient of indirect promotion effect (the effect on IE of neighboring provinces) is 0.9691 , the total effect is 2.5436 , all passed the $1 \%$ significance level. The coefficients of the direct promotion effect, indirect promotion effect and total effect of $\mathrm{Ln}\left(\mathrm{AP}^{2}\right)$ on IE are significant at the $1 \%$ statistical level, and the values are $-3.5053,-2.1586$, and -5.6639 respectively. Hence, the short-term AP has not only promoted IE in its province, but also has increased IE in neighboring provinces through spatial effect. With deepening of AP, inhibiting IE of itself and neighboring provinces.

TABLE VI. The results of the spatial effect

\begin{tabular}{|c|c|c|c|c|}
\hline \multirow[t]{3}{*}{ VARIABLES } & (1) & $(2)$ & (3) & (4) \\
\hline & MODEL & \multicolumn{3}{|c|}{ SPATIAL EFFECT DECOMPOSITION } \\
\hline & SAR & DIRECT EFFECT & INDIRECT EFFECT & TOTAL EFFECT \\
\hline $\mathrm{AP}$ & $\begin{array}{l}1.474^{* * *} \\
(6.270)\end{array}$ & $\begin{array}{l}1.574^{* * * *} \\
(6.609)\end{array}$ & $\begin{array}{l}0.969^{* * * *} \\
(4.014)\end{array}$ & \begin{tabular}{|l}
$2.543^{* * * *}$ \\
$(6.936)$
\end{tabular} \\
\hline $\mathrm{LN}\left(\mathrm{AP}^{2}\right)$ & $\begin{array}{l}-3.270 \\
(-5.323) \\
\end{array}$ & $\begin{array}{l}-3.505 \\
(-5.505)\end{array}$ & $\begin{array}{l}-2.158 \\
(-3.656)\end{array}$ & $\begin{array}{l}-5.663^{*} \\
(-5.619)\end{array}$ \\
\hline $\mathrm{MC}$ & $\begin{array}{l}-0.060^{* * *} \\
(-3.319)\end{array}$ & $\begin{array}{l}-0.062^{* * *} \\
(-3.362)\end{array}$ & $\begin{array}{l}-0.038^{* *} \\
(-2.417)\end{array}$ & $\begin{array}{l}-0.100^{* * *+1} \\
(-3.130)\end{array}$ \\
\hline LNED & $\begin{array}{l}1.549 \\
(3.607)\end{array}$ & $\begin{array}{l}1.611^{* 26} \\
(3.961)\end{array}$ & $\begin{array}{l}0.981 \\
(3.373)\end{array}$ & $\begin{array}{l}2.592 * \cdots \\
(4.219)\end{array}$ \\
\hline $\mathrm{IL}$ & $\begin{array}{l}-0.320 \\
(-6.287)\end{array}$ & 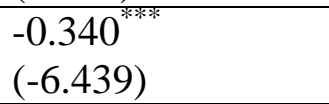 & \begin{tabular}{|l|l|}
$-0.214^{* * * * *}$ \\
$(-3.034)$
\end{tabular} & \begin{tabular}{|l}
$-0.554^{* * * *}$ \\
$(-4.992)$
\end{tabular} \\
\hline TC & $\begin{array}{l}0.020^{* * * * * *} \\
(2.689)\end{array}$ & $\begin{array}{l}0.021^{* * * *} \\
(2.689) \\
\end{array}$ & $\begin{array}{l}0.013^{* *} \\
(1.996)\end{array}$ & $\begin{array}{l}0.035^{* *} \\
(2.509)\end{array}$ \\
\hline EP & $\begin{array}{l}0.025 \\
(1.129) \\
\end{array}$ & $\begin{array}{l}0.027 \\
(1.106) \\
\end{array}$ & \begin{tabular}{|l|}
0.017 \\
$(1.014)$
\end{tabular} & \begin{tabular}{|l|}
0.045 \\
$(1.088)$ \\
\end{tabular} \\
\hline$\rho$ & $0.415^{* * * *}$ & & & \\
\hline
\end{tabular}


Article History: Received: 10 May 2021 Revised: 20 June 2021 Accepted: 18 July 2021 Publication: 31 August 2021

\begin{tabular}{|l|l|l|l|l|}
\hline & $(5.719)$ & & & \\
\hline SIGMA2 & $\begin{array}{l}0.742^{* * *} \\
(8.917)\end{array}$ & & & \\
\hline OBSERVATIONS & 165 & 165 & 165 & 165 \\
\hline R-SQUARED & 0.726 & 0.726 & 0.726 & 0.726 \\
\hline
\end{tabular}

Note: $* * *, * *, *$ indicate the significance level of $1 \%, 5 \%$, and $10 \%$ respectively. The value in () indicates the standard error of the estimated coefficient, the value in [] represents the $p$ value.

\section{CONCLUSIONS AND POLICY SUGGESTIONS}

The paper, based on the empirical data of 11 provinces in western China from 2004 to 2019, studies the inverted U-shape of an aging population on innovation in entrepreneurship from spatial effects and human capital intermediary effects. We examined the past studies, but the research context and sample data are different, which expands the inverted U-shaped adaptation range of an aging population and innovation in entrepreneurship. Besides, extending the research scope of the relationship between the two. The results show that:

First, the aging population in western China is constantly deepening, and developing breaking through the geographical limits. For example, the aging of Sichuan and Chongqing has ranked in the forefront of China [51]. Second, human capital will increase the inverted U-shaped of an aging population on innovation in entrepreneurship. The western China is still in a demographic dividend period, but as the aging population to deepen, lessening the effective supply of labor in western China, and inhibiting innovation in entrepreneurship [16]. Third, innovation in entrepreneurship and the aging population both show significant spatial agglomeration characteristics. Based on the results of past studies, the impact of an aging population on entrepreneurship shows spatial differences [36]. The article further points out the inverted U-shaped of an aging population on innovation in entrepreneurship has spatial effects, which extend the past results.

Facing the contradiction between deepening aging population and innovation in entrepreneurship, based on the conclusions, policy suggestions is following:

First, increasing investment in human capital and playing fully to the crowding effect of aging. Human capital is an important source of the sustainable development of innovation. China's labor supply has gradually shifted from a quantitative demographic dividend to a qualitative demographic dividend to build an innovative country. China's western region can continue to rely on its own advantages to improve the talent attraction policy. Increasing education and training investment, strengthening vocational skills trains to improve the quality of the labor force. Reasonably to develop for the elderly, pass on their own experience and technology to young people, and provide valuable and experienced labor for enterprises in 
need.

Second, expanding the spillover of knowledge store on aging and promote collaborative innovation among enterprises across provinces. Innovation of enterprises in western China needs not only new ideas and inspiration brought by a stream of young people, but also the knowledge and experience provided by new senior talents who can take root in the western China for a longtime. We should rationally treat the negative effects of an aging population on innovation in entrepreneurship of local and neighboring provinces, strengthen cooperation between enterprises in western China, and maximize the knowledge integration brought by aging population among provinces, and then promote the joint development of enterprise innovation between provinces.

\section{ACKNOWLEDGEMENT}

This research was supported by National Social Science Foundation of China (Grant No. 17BJY041), Humanities and Social Sciences Key Cultivation Project of Qinghai Nationalities University in China (Grant No. 20190515).

\section{REFERENCES}

[1] He CF, Lu JY., Qian HF (2019) Entrepreneurship in China. Small business economics 53(3):563-572.

[2] Zhang J (1996) Research on China's population aging. Long-jiang social sciences 3(4):41-58.

[3] Lee R, Mason A (2010) Fertility, human capital, and economic growth over the demographic transition. European journal of jopulation/revue européenne de démographie 26(2):159-182.

[4] Chen XY (2014) The mechanism of population aging affecting economic development and its countermeasures: Taking foreign developed countries as examples. Modern economic research 21(5):83-87.

[5] Yao DM, Li SX, Lin SS (2015) Will aging affect scientific and technological innovation--a literature analysis based on age structure and innovation ability. Management review 27(8):56-67.

[6] Huang Q, Li XB, Li JB (2018) The impact of iopulation aging on innovation: an empirical study based on China's macro and micro data. Modern economic research 25(12):25-32.

[7] Czaja SJ, Lee CC (2007) The impact of aging on access to technology. Universal access in the information society 5(4):341-349.

[8] Wu CP, Yang QF (2011) Being good for the elderly is an objective requirement for our country to actively respond to the aging of the population. Population and development 17(6):32-34.

[9] Cole S (1979) Age and scientific performance. American journal of sociology 84(4):958-977.

[10] Park J, Kim S (2015) The differentiating effects of workforce aging on exploitative and exploratory innovation: The moderating role of workforce diversity. Asia pacific journal of management 32(2):481-503. 
[11] Lavoie M (2009) Aging population and innovations skills/Vieillissement demographique et competences d'innovation/Envejecimiento demografico y competencias de innovacion. Industrial relations 64(4):641-662.

[12] Ang JB, Madsen JB (2015) Imitation versus innovation in an aging society: international evidence since 1870. Journal of population economics 28(2):299-327.

[13] Hsu M, Liao PJ, Zhao M (2018) Demographic change and long-term growth in China: past developments and the future challenge of aging. Review of development economics 22(3): 928-952.

[14] Gao Y (2017) Does population aging affect scientific and technological innovation? An empirical study based on China's provincial panel data. Science and technology progress and countermeasures 34(17):46-51.

[15] Shen L, Guo Y (2020) Study on the impact of aging on the technological innovation of high-tech industry--based on the analysis of sub-industry and enterprise scale heterogeneity. Industrial Technology \& Economy 39(12):78-87.

[16] Sui SM, He ZH (2020) The impact of population aging on enterprise innovation--an empirical analysis based on census data and micro-industrial enterprise data. Population Research 44(6):63-78.

[17] Loug Y, Wang LY, Hao FX (2020) Analysis of the impact of population aging on my country's scientific and technological innovation. Science and technology management research 40(21):14-22.

[18] Li H (2021) Aging population, medical burden and micro-human capital investment. Statistics and decision 37(2):88-92.

[19] Mincer J (1996) Economic development, growth of human capital, and the dynamics of the wage structure. Journal of economic Growth 1(1):29-48.

[20] Lu J, Liu L, Guo ZY (2018) The influence mechanism of China's population aging on the industrial structure--an empirical analysis based on synergy and intermediary effects. China Population Science 32(3):15-25.

[21] Tobler WR (1970) A computer movie simulating urban growth in the Detroit region. Economic geography 46(1):234-240.

[22] We J (2003) Analysis of the knowledge spillover effect of small business cluster innovation network. Scientific research management 24(4):54-60.

[23]Yu YZ (2011) Agglomeration of innovation factors, government support and technological innovation efficiency: spatial panel measurement analysis based on provincial data. Economic review 22(2):93-101.

[24] Chen JL (2021) Study on the impact of senior management connection on the innovation performance of manufacturing enterprises. Scientific research management 42(1):200-208.

[25] Chang L, Ao RJ (2021) Study on the temporal and spatial pattern of population aging in border counties and districts in China and its influencing factors. World geographical research 30(2):410-421.

[26] Liu JG, Zhong XP (2021) The impact of healthy consumption on high-quality economic development from the perspective of aging. Statistics and decision 37(5):65-70.

[27] Wang JF, Xu CD (2017) Geographic detectors: principles and prospects. Acta geographica sinica 72(1):116-134.

[28] Wang ZB, Sun TH, Li GP (2013) The regional differences and evolution of population aging in China in the past 20 years. Population research 37(1):66-77. 
[29] Yuan J, Wu DT, Wu ZZ (2007) Analysis of the spatial differences and influencing factors of the aging of rural population in China. China population science 21(3):41-47.

[30] Zhou Y, Deng F, Zhuo CF (2020) Has the demographic dividend subsidence hindered the rise of my country's manufacturing value chain. Inquiry into economic issues 41(4):13-26.

[31] Zhang AL, Yin ML (2019) Research on the heterogeneous threshold effect of population aging on regional technological innovation. Soft science 33(11):35-40.

[32] Li XL (2019) Regional green economic growth: measurement, decomposition and driving Factors--empirical data from Japan. Journal of Hebei university of economics and trade 40(5):24-34.

[33] Hebert RF, Link AN (1989) In search of the meaning of entrepreneurship. Small business economics 1(1):39-49.

[34] Li HB, Li X, Yao XG, Zhang HF, Zhang JS (2009) The influence of entrepreneurs' entrepreneurial and innovative spirit on China's economic growth. Economic research 55(10):99-108.

[35] Hu GL, Zhao Y, Hu J (2019) D\&O insurance, risk tolerance and independent innovation of enterprises. Management world 35(8):121-135.

[36] Yu J, Yang HY, Zhou DH, Chen MX (2020) The temporal and spatial differences and path mechanism of population aging and entrepreneurship--Research on regression model based on provincial panel data. Investigation in economic issues 41(12):66-78.

[37] Cheng JJ (2016) System changes, entrepreneurship and the development of private economy. Economic management 38(8):39-54.

[38] Zhang GX, Feng YC, Wang AL (2021) Study on the heterogeneity effect of different types of environmental regulations on the technological innovation of industrial enterprises. Management review 33(1):92-102.

[39] Chen YJ, Cong ZW (2017) Better play the role of the government in regional market integration. Finance and trade economics 38(2):5-19.

[40] Yang MH, Liu KQ, Xie SS (2021) Educational human capital, healthy human hapital and green technology innovation: the moderating role of environmental regulation. Economics and management review 37(2):138-149.

[41] Ma ZL, Tian SY (2016) Externalities of ecological capital, human capital accumulation and innovation. Journal of Jiangxi university of finance and economics 18(2):3-10.

[42] Huang RX, Wei P, Pan XZ (2021) The spatial effect of higher education human capital agglomeration on technological innovation: an empirical analysis based on prefecture-level cities in Hubei Province. China higher education research 37(1):70-76.

[43] Li CQ, L YK, Li ML (2018) Controlling shareholder equity pledge and enterprise innovation investment. Financial research 61(7):143-157.

[44] Chen Y, Feng YT (2016) Informal employment and the process of marketization: a spatial measurement verification based on panel data. Journal of demography 38(6):99-110.

[45] Baron MN, Kenny DA (1986) The moderator mediator variable distinction in social psycholo-gical Rresearch: conceptual, strategic and statistical consideration. Journal of personality and social psychology 51(6):1173-1182.

[46] Anselin L (1988) Lagrange multiplier test diagnostics for spatial dependence and spatial heterogeneity. Geographical analysis 20(1):1-17. 
[47] Anselin L, Florax RJ (2018) New directions in spatial econometrics: introduction. Berlin: Springer-Verlag.

[48] Greene WH (2018) Econometric Analysis.8th Edition. New York: pearson.

[49] Wang C, Chen XX, Zhu XJ (2014) Age structure and entrepreneurship: an empirical analysis based on China's provincial data. Contemporary economic research 25(7):76-81.

[50] Wang W, Jiang ZM (2016) A review of researches on the impact of population aging on technological progress. China population science 30(3):114-125.

[51] Hao L, Zhang QW (2020) A new indicator to measure population aging. Statistics and decision 36(20):5-8. 